\title{
A case for MOOCs in Indian Higher Education System
}

\author{
P. N. Rao ${ }^{1 *}$, M. Komaraiah ${ }^{2}$, P. Narasimha Reddy ${ }^{3}$. \\ ${ }^{1}$ Visiting Professor, ${ }^{*}{ }^{2}$ Professor, ${ }^{3}$ Executive Director \\ ${ }^{1,2,3}$ Sree Nidhi Institute of Science and Technology, Yamnampet, Ghatkesar, Hyderabad - 501 301, India \\ *Department of Technology, University of Northern Iowa, Cedar Falls, IA 50614-0178, USA. \\ 1posinasetti@gmail.com, ${ }^{2}$ profmkou@yahoo.com, ${ }^{3}$ nrporeddy@sreenidhi.edu.in
}

\begin{abstract}
Massive open online courses (MOOC) have started in 2008 but the interest has really exploded since 2012. The proliferation of MOOCs happened because of the maturing of many of the technologies such as the wide availability of low cost broadband, cheaper laptops, tablets, and smart phones, expanded cellular network, cloud storage and computing and social networking. The need for low cost education for masses has been felt and MIT started the open courseware movement, which has been followed by many other big universities. This has naturally progressed into MOOC and a large number of MOOCs have been made available. Because of the openness and online,eager students particularly from developing nations have lapped up MOOCs.

India also followed with the IITs and IIM providing them in a small way. There were also efforts to make the MOOCs for credit by some universities. The structure of a MOOC is slightly different from traditional classroom based courses in order to keep the attention of the online student with the course. Therefore, it is necessary to follow the best practices that have proven successful with the MOOCs that are already available.
\end{abstract}

\footnotetext{
P. N. Rao $^{1^{*}}$

${ }^{1}$ Visiting Professor, "Professor

${ }^{1}$ Sree Nidhi Institute of Science and Technology, Yamnampet, Ghatkesar, Hyderabad, India

"Department of Technology, University of Northern Iowa, USA. posinasetti@gmail.com
}

For Indian higher education system, MOOCs actually would provide a very convenient model to impart quality education across a large number of private institutions. It is important to consider a viable model for offering MOOCs as part of regular university curriculum and offer credit at the same time having the flexibility of taking free courses. This paper offers such a model for Indian universities.

Keywords : Higher education, MOOC,India, University, Open education

\section{Introduction}

The open courseware (OCW) initiative of Massachusetts Institute of Technology (MIT)has paved the way for accessing quality educational material for masses in the twenty first century. Massive Open Online Course (MOOC)is a phenomenon that started in 2008 but has received a lot of interest from all quarters in such a short time to make it as one of the most important development in educating masses at low cost. MOOC is available free online and can be accessed by everybody with a computer and internet access.It is meant to help spread the education to everybody with minimal cost and aims at a large-scale interactive participation of users with the help of web. The education delivery in the form ofMOOC is defined as, "massive, with theoretically no limit to enrollment; open, allowing anyone to participate, usually at no cost; online, with learning activities typically taking place over the web; and a course, structured around a set of learning goals in a defined area of study" (Educause, 2013). 
MOOCs have become a reality today because of the developments in technology. The various technologies that have matured and have become the enablers for MOOCs are:

Broadband: Today high-speed broadband penetrated to large areas of major nations and is available at relatively low cost.

Consumer devices: Today there are large varieties of consumer devices are available that can access internet such as laptops, chrome books, tablets and smart phones. The prices of these devices are falling continuously and it is difficult to find someone without it.

Cloud and web services:Along with the broadband, cloud computing and storage have become commonplace. In addition, the cloud storage and services have become cheaper and more commonplace. All the consumer devices link with the cloud.

Social networking: The social networking sites such as Facebook, twitter, Google+, WhatsApp, are now regularly used by the modern generation. They are more comfortable with the use of internet.

In view of the above-mentionedtechnologies, the current generation will be better served by the technology in the form of MOOC.As a result, large number of professors from different universities around theworld are nowofferingMOOCs in a number of disciplines. A number of platforms such as Coursera, edX, Udacity, and FutureLearn have been made available by reputed universities such as MIT, Harvard, Stanford and UK Open University. Cofounder of Coursera, Daphne Koller feels that MOOCs will transform, not disrupt,higher education and leverage technology to improve quality. She states, "We don't believe that computers should replace teachers. We think computers can enhance the work of teachers"(Korn, 2013).

MOOCs have many advantages compared to the tradition educational systems. The main advantages of MOOCs are:

1. The main advantage is that enrolment is open to anybody in the World, without any fee, and no prerequisites. Also absolutely no commitment from the student about the completion of the course.

2. It is completely flexible and the student can spend any amount of time, any time that he/she likes and spread the learning process as long as he/she wants.

3. The way the MOOCs will be designed is to increase the involvement of the student with the course in the form of short videos, animations, simulations, simple quizzes, etc. to inculcate curiosity among the student and let him/her to continue the learning process.

4. They provide better experience than a simple classroom lecture oriented course because of the access to the curated material. MOOCs include material that is specifically designed for the course as well as the curated material that is already available on the web that will be relevant for the course material understanding. The curated material will provide the student with the application relevance of the concept where feasible.

5. Students are likely to spend a lot of time in the discussion forum to learn from each other. It is possible to form a lifelong association with people whom you may or may not meet in person thanks to MOOC. Experience gained with the MITx prototype course 6.002x course (Brown, 2013) is a very good example.

6. It will be a lifelong learning process for everybody. It is an excellent way to support career opportunity by diligently planning and taking these required MOOCs from a variety of options available globally at the convenience of the learner. It will also be possible that some people will be thinking about taking these courses purely for knowledge sake without thinking about any degrees, certificates or rewards.

There are also equal number of challenges that are associated with the MOOCs.

1. The student should have access to a computer with internet. This may or may not be available in some poor countries.

2. Though a large number of people register for the courses, there is, a large dropout rateexperienced by most of the courses. The number of people who actually complete a MOOC rarely goes beyond 10\% of the initial registration. There are many reasons specified by those dropping out such as lack of time, only interested to know the course material and not the assessment, etc.

3. Currently there is no accreditation for a MOOC (Naidu and Barberà, 2014). Though MOOCs are actually offered by well-known universities and 
professors that have long experience in teaching these courses, the quality of the course is going to be dictated by their self-regulation and standards that they would like to adhere to. Sometimes the MOOC platform provider would try to enforce certain standards of quality.

4. Automated grading is possible with multiplechoice questions. However it is not possible to completely evaluate the proficiency in a particular course with multiple-choice questions alone. Assignments and examinations therefore need to be evaluated by humans in the form of teaching assistants. In such cases maintaining uniformity among the graders need to be paid special attention.

5. The actual effort that needs to be put in to develop a completely interactive course that will be taken by different people with different languages and learning styles will be very large compared to a conventional lecture course. It will be challenging for the instructor to develop the material to make sufficiently interesting to the diverse group of students.

6. Some students may like to have individualized instruction with one-on-one with the instructor. For such students MOOCs may not be the solution.

7. MOOCs are free to the students but will be an enormous burden for the universities. Therefore, there need to be some kind of a business model to recoup the costs involved beyond the experimental stage. Otherwise, they are likely to fail in the long run.

8. Assuring academic integrity of the MOOCs will be a problem. It is necessary to develop some standards in this regard and a number of agencies are already working towards that aspect.

9. "Institutions should also consider the effect that running MOOCs may have on the staff who are required to run them and whose job satisfaction would diminish considerably if the sole teaching component of their job was to facilitate MOOCs" (Walker and Loch, 2014).

\section{Historical Development}

Distance education has been providing opportunities for students who were not able to get into the universities and colleges because of many problems for quite some time. In the nineties digital technologies have been increasingly started using in education in the form electronic versions of class notes, textbooks, and web resources. In addition, the availability of learning management systems (LMS) such as WebCT, Blackboard, helped in enhancing the classroom experience with other resources that were available elsewhere for the students. MIT announced in October 2002 their open course initiative to make available the course material for anyone interested freely. That followed the Open Courseware Consortium that included a large number of other famous universities across the globe to participate in the program to provide a large range of education material available freely for anyone who would like to educate.

Khan Academy created by educator Salman Khan in 2006 primarily to teach mathematics concepts to his cousins in the form of short and simple doodles. When the need was felt for wider audience, he decided to make them freely available on YouTube. The popularity of these videos has allowed Salman Khan to expand the repertoire to other subjects with funding from philanthropic organizations such as Bill and Melinda Gates Foundation. The format is essentially consists of brief YouTube videos, mixed illustrations, practice exercises and discussion forums. Though this is not a MOOC is certainly a precursor to MOOC.

George Siemens of Athabasca University and Stephen Downes of the National Research Council have offered the first MOOC in 2008,CCK08: Connectivis a n Connective Knowledge. Theywanted to exploit the possibility for interactions between a wide variety of participants with the help of online tools so that it will provide a richer learning environment than the conventional classroom. The term MOOC was actually coined in 2008 by Dave Cormier of the University of Prince Edward Island (Wikipedia). The course CCK08 has 25 tuition-paying students from University of Manitoba and 2300 online no fee students. All course content was available through RSS feeds and online students could participate through collaborative tools, including blog posts, threaded discussions in Moodle LMS and Second Life meetings. This type of course is called cMOOC.

Later in the fall of 2011, Peter Norvig and Sebastien Thrun from Stanford University offered their CS221 Introduction to Artificial Intelligence free and online to students worldwide from October 10thto December 18th,2011. This is the same course as taught in Stanford. A total of 160,000 students from 
190 countries enrolled in this course, and 20,000 successfully completed the course. Stanford also offered two other MOOC courses at the same time; Machine Learning (104,000 registered and 13,000 completed the course) and Introduction to Databases (92,000 registered, 7,000 completed).This type of courses are called XMOOCs that are focused less on interaction between students and more on exploiting the possibilities of reaching a massive audience.

At the same time,Massachusetts Institute of Technology (MIT)has developed the MITx platform for offering MOOCs. A similar effort was going on at Harvard called Harvardx. A non-profit consortium called edX was formed as a MOOCs platform with $\$ 60$ million funding from MIT and Harvard University to support the project. In addition to the founders, edX now has a number of Universities throughout the world as partners. Currently, there are $538+$ courses including chemistry, computer science, electronics and public health.For a small fee, students can take an assessment, which, if successfully completed, will provide them with a certificate from edX. MITx and Harvardx courses will not be offered for credit at either university. The consortium has made available an open source version of the platform, which can be used and developed by other institutions and individuals.

Sebastien Thrunfounded a company called Udacity in February 2012with \$21.1 million investment from venture capitalist firms.Udacity currently offers $90+$ courses in computer science, mathematics, general sciences, programming and entrepreneurship. It offers short courses as modules which when combined can be given as Nano degree. Some universities began offering transfer credit for Udacity students who then take the final examination at a Pearson centre. It also collaborated with Georgia Tech University to offer a MS degree in computer science in four specializations.

Andrew Ng and Daphne Koller, from Stanford started another company called Coursera in April 2012. Coursera is a for-profit company started with \$22 million total investment from venture capitalists. Initially Stanford, Princeton, Michigan and Pennsylvania Universities were the participants. Later on a large number of other universities globally joined courser offering their courses. Coursera currently has more than 866 courses in various disciplines. Some partner universities offer credit for their Coursera classes to those who want to pay a fee to have some extra assignments, work with an instructor, and be assessed.

In 2013, the UK Open University offered its own MOOC platform, Futurelearn. It has 60 partners from around the world including the best UK and international universities, as well as institutions such as the British Council, the British Library, the British Museum, and the National Film and Television School.

A timeline of the development of MOOC is presented in Fig 1 (UNESCO, 2013). Some of the key characteristics that distinguish the different MOOC platforms are given in Table 1 (Taneja and Goel, 2014). Table 2 presents a sample of various other MOOC platforms that are currently available.

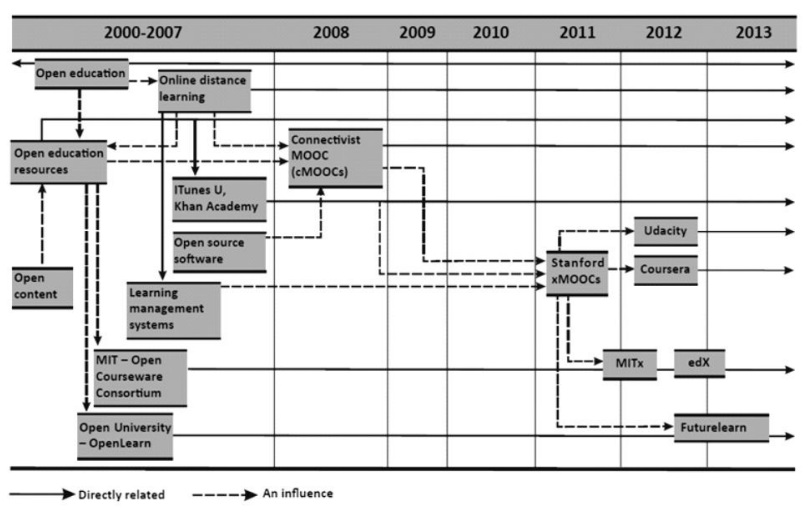

Fig. 1 Time line of MOOC development (UNESCO, 2013)

Table 1 Comparison of the key characteristics of some of the MOOC platforms(Taneja and Goel, 2014).

\begin{tabular}{|c|c|c|c|}
\hline & Coursera & edX & Udacity \\
\hline $\begin{array}{l}\text { Available } \\
\text { languages }\end{array}$ & $\begin{array}{l}\text { English, Spanish, } \\
\text { French, Chinese, } \\
\text { Arabic, Russian, } \\
\text { Portuguese, Turkish, } \\
\text { Ukrainian, Hebrew, } \\
\text { German, Italian, } \\
\text { Arabic, Greek, } \\
\text { Japanese }\end{array}$ & $\begin{array}{l}\text { English, } \\
\text { Mandarin, } \\
\text { French, } \\
\text { Hindi, Spanish }\end{array}$ & English \\
\hline Accreditation & $\begin{array}{l}\text { American Council on } \\
\text { Education's College } \\
\text { Credit } \\
\text { Recommendation for } \\
\text { Five courses }\end{array}$ & $\begin{array}{l}\text { Universities do } \\
\text { not offerformal } \\
\text { academic credit } \\
\text { for edX course } \\
\text { work Open } \\
\text { platform }\end{array}$ & $\begin{array}{l}\text { Tie up with } \\
\text { Georgia Tech } \\
\text { university to } \\
\text { offer MS in } \\
\text { Technology }\end{array}$ \\
\hline Technology & Closed platform & $\begin{array}{l}\text { Courses from } \\
\text { top universities }\end{array}$ & Closed platform \\
\hline $\begin{array}{l}\text { Market } \\
\text { strategy }\end{array}$ & $\begin{array}{l}\text { Broad set of courses } \\
\text { in subjectslike, } \\
\text { physics, engineering, } \\
\text { humanities, medicine, } \\
\text { biology, social } \\
\text { sciences, mathematics, } \\
\text { business, computer } \\
\text { science, and many } \\
\text { more }\end{array}$ & $\begin{array}{l}\text { for post college } \\
\text { life long } \\
\text { learners }\end{array}$ & $\begin{array}{l}\text { Focus on } \\
\text { Vocational } \\
\text { courses/ } \\
\text { courses in } \\
\text { STEM fields }\end{array}$ \\
\hline
\end{tabular}


Table 2. A sample of the current MOOC providers MOOC Platform Website

\begin{tabular}{|c|c|c|}
\hline & MOOC Platform & Website \\
\hline 1 & $\begin{array}{l}\text { Initiative } \\
\text { lallo }\end{array}$ & http://oli.cmu.edu/ \\
\hline 2 & COURSERA & https://www.coursera.org/ \\
\hline 3 & EDRAAK - Arab MOOC Platform & https://www.edraak.org/ \\
\hline 4 & $\mathrm{EdX}$ & https://www.edx.org/ \\
\hline 5 & Enaco - Business school & http://www.enaco.fr/mooc/ \\
\hline 6 & EWANT - Chinese & $\underline{\text { http: } / / \text { www.ewant.org/ }}$ \\
\hline 7 & Fort Hays State University & http://www.fhsu.edu/ \\
\hline 8 & FUN - France's National MOOC plafform & http://www.france-universite-numerique.fr/moocs.html \\
\hline 9 & FUTURELEARN, INC. & http://www.futurelearn.com/ \\
\hline & iMooX - Austrian MOOC Platform & $\underline{\text { http://imoox.at/wbtmaster/startseite/ }}$ \\
\hline & Institute des Mines-Telecom & http://www.mines-telecom.fr/en/ \\
\hline & Iversity & $\underline{\text { https://iversity.org/ }}$ \\
\hline & LUXVERA & $\underline{\text { http://luxvera.regent.edu/ }}$ \\
\hline & MIRIADAx - Spanish, Portugese & $\underline{\text { https: } / / \text { www.miriadax.net/ }}$ \\
\hline & MOOCFACTORY & $\underline{\text { http://moocs.epfl.ch/mooc-factory }}$ \\
\hline & MOOEC - English & $\underline{\text { http: } / / \text { www.mooec.com/about }}$ \\
\hline & MR UNIVERSITY - Economics & $\underline{\mathrm{http}: / / \text { mruniversity.com/ }}$ \\
\hline & Najah National University & $\underline{\text { http://elc.najah.edu/node/304 }}$ \\
\hline & OpenCourseWorld & https://www.opencourseworld.de/pages/landingpage.jsf \\
\hline & OpenHPI & $\frac{\text { https://open.hpi.de/ }}{\text { http://Www.open.edu/openlearn/about- }}$ \\
\hline & OpenLearn - UK Open University & openlear/frequently-asked-questions-on-openleam \\
\hline & OPEN2STUDY - Australian & $\underline{\mathrm{https}: / / \text { www.open2study.com/ }}$ \\
\hline & OpenUpEd - EU & http://www.openuped.eu/ \\
\hline & Rwaq - Arabic Saudi & $\underline{\mathrm{http}: / / \text { rwaq.org/ }}$ \\
\hline & Stanford University Open online courses & $\underline{\text { http: } / / \text { online.stanford.edu/courses }}$ \\
\hline & Tsinghua University & $\underline{\text { https: //www.xuetangx.com }}$ \\
\hline & UDACITY & $\underline{\text { https://www.udacity.com/ }}$ \\
\hline קט & UniM00C & $\underline{\text { http://unimooc.com/landing/index.html }}$ \\
\hline 29 & Universidade Aberta - iMOOC & $\underline{\text { http: } / / \text { imooc.uab.pt/ }}$ \\
\hline 30 & UNEDCOMA & www.unedcoma.es \\
\hline 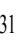 & Universidad Politecnica de Madrid & $\underline{\text { http: }: / \text { www.upvx.es/ }}$ \\
\hline & University of Amsterdam & http://mooc.uva.nl/portal \\
\hline & University of Califomia - Irvine: OpenCourseware & $\underline{\text { http://ocw.uci.edu/info/ }}$ \\
\hline & Veduca - Brazil & $\underline{\text { http://www.veduca.com.br/ }}$ \\
\hline & Yale Open Courses & $\underline{\text { http://oyc.yale.edu/ }}$ \\
\hline
\end{tabular}

\section{Some MOOC experiences}

As MOOC is a recent phenomenon not much of research has gone into the quality and pedagogy of the courses that are offered through this method. Kennedy (2014) reviewed the various papers published on MOOC based on the early offerings. The key findings of the review are all the MOOCs have varied definitions of openness, barriers to persistence, and utilized one of two pedagogical approaches, i.e. cMOOC and xMOOC.The high dropout rates experienced among the first group of MOOCs show that the barriers to learning are a significant challenge.The author found that the connectivist
MOOC model (cMOOC)relates to social learning theories such as social constructivism (Kop, 2011) while the Stanford Artificial Intelligence (AI) model (xMOOC) uses the conventional directed instruction in higher education institutions which is categorized as cognitive-behaviorist (Rodriguez, 2012). The audience for these two types of pedagogies is different.

McGreal et al. (2014)investigated the assessment and accreditation of MOOCs in higher education. They used a survey for the purpose. They find that many universities are reluctant to reuse open-licensed courses and their corresponding assessments. In the traditional setup, people have faith in Higher EducationUniversity to provide standards. However, in the case of open educational resources (e.g. MOOCs) it is necessary to have some kind of assessment and accreditation services to help with the process.

Walker and Loch (2014) investigated through a survey of those who participated as students in aMOOC. This survey is followed with a focus group of academics to discuss the pedagogicaldesign and the broader implications that MOOCs have for the higher education sector. Thesurvey participants havenegative perceptions of the pedagogy of MOOCS, similar to that described by Vardi (2012) on the quality of resources and the style of courses. However, many learning designers tended to side with de Waard et al. (2011) and Mackness et al. (2010)at the positives and the potential of MOOCs to engage students in deep learning.

Selwyn et al. (2015) presents the way MOOCs have been covered in the newspapers. From an analysis of 457 newspaper articles published between 2011 and 2013, the newspapers seem to concentrate on the massive scale, marketing and business side of MOOC. The newspapers did not discuss 'technological' and 'educational' issues such as online learning and pedagogy, instructional design or student experience of the MOOCs. The newspapers are more interested in the economics of higher education and how MOOCs are likely to provide a radical departure from the existing systems.

Toven-Lindsey et al.(2015) explored the range of pedagogical tools used in 24 different MOOCs, to consider the extent towhich these courses provide students withhigh-quality, collaborative learning experiences. They found that the range of pedagogical 
practices currentlyused in MOOCs that they studies tends toward an objectivist-individual approach, with some efforts to incorporate more constructivistand group-oriented approaches. The authors are concerned that the degree to whichMOOCs are not really revolutionizing higher educationby using technology to improve quality.

Margaryan et al. (2015) analyzed the instructional design quality of 76 randomly selected Massive Open OnlineCourses (MOOCs). They found that the majority of MOOCs scoredpoorly on most instructional design principles. However, most MOOCs scored highly on organisation andpresentation of course material. The results indicate that although most MOOCs are wellpackaged, theirinstructional design quality is low.

Chang et al. (2015) investigated the influence of learning styles on the learners' intentions to use MOOCs using a survey instrument with 184 undergraduate students. Some of these students (64) have actually used MOOCs. They found that there is a $90 \%$ probability that the type of learning styles does influence learner intentions. The results showed that learners with a high-reflective learning style tended to have less experience in using MOOCs. Finally, they have identified the learning approaches that could assist learning in MOOCs and examined the correlation between learning styles and user intention. Some of their observations from the participants are shown in Fig. 2 and 3.

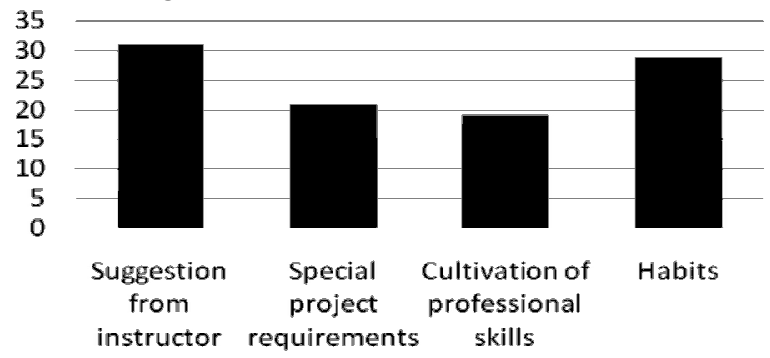

Fig 2Reasons for the learners to use MOOCs (Data from Chang et al., 2015)

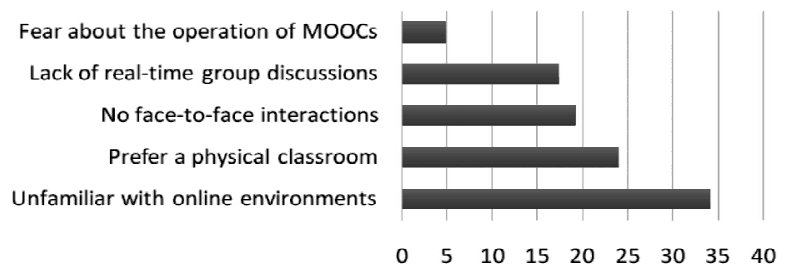

Fig 3 Reasons for not participating in MOOCs (Data from Chang et al., 2015)

\section{Structure of a MOOC}

Many instructional design methods have been proposed and are used in different situations. The ARCS model suggested by Keller $(1987,1999)$ is generally found to be quite useful forelearning. Keller's ARCS model is based on a synthesis of motivational concepts and characteristics into the four categories of attention (A), relevance (R), confidence $(C)$, and satisfaction (S). These four categories represent sets of conditions that are necessary for a person to be fully motivated, and each of these four categories has component parts, or subcategories (Table 3), that represent specific aspects of motivation.

Table 3 ARCS model of instructional design

\begin{tabular}{|l|l|l|}
\hline Category & Definition & Basic tactics \\
\hline Attention & $\begin{array}{l}\text { Capturing the learner's } \\
\text { interest; stimulating } \\
\text { curiosity to learn }\end{array}$ & $\begin{array}{l}\text { - Perceptual arousal: capturing learner } \\
\text { interest } \\
\text { - Inquiry arousal: stimulating an attitude } \\
\text { of inquiry } \\
\text { - Variability: maintaining learner } \\
\text { attention over time }\end{array}$ \\
\hline Relevance & $\begin{array}{l}\text { Meeting the learner's } \\
\text { needs and goals, } \\
\text { effecting a positive } \\
\text { outcome }\end{array}$ & $\begin{array}{l}\text { Goal orientation: meeting learner's } \\
\text { needs } \\
\text { - Motive matching: providing learners } \\
\text { with appropriate choices, } \\
\text { responsibilities, and influences } \\
\text { - Familiarity: tying instruction to } \\
\text { learner's experiences }\end{array}$ \\
\hline Confidence & $\begin{array}{l}\text { Helping the learner build } \\
\text { the belief that } \\
\text { he/she will succeed, and } \\
\text { giving the learner } \\
\text { control over his/her } \\
\text { success }\end{array}$ & $\begin{array}{l}\text { Learning requirements: building a } \\
\text { positive expectation for success } \\
\text { - Success opportunities: enhancing } \\
\text { learners' beliefs in their competence } \\
\text { - Personal control: illustrating that } \\
\text { learner success is based on their efforts } \\
\text { and abilities }\end{array}$ \\
\hline Satisfaction & $\begin{array}{l}\text { Reinforcing the learner's } \\
\text { accomplishments with } \\
\text { internal/external rewards }\end{array}$ & $\begin{array}{l}\text { Natural consequences: providing } \\
\text { meaningful opportunities for learners to } \\
\text { use their newly acquired knowledge } \\
\text { - Positive consequences: providing } \\
\text { reinforcement to learners' success } \\
\text { - How can I assist the students in } \\
\text { anchoring a positive feeling about their } \\
\text { accomplishments? }\end{array}$ \\
\hline
\end{tabular}

The structure of an xMOOC though follows the traditional lecture format of the regular classroom, needs to provide different aspects to allow for the ARCS model as given above. There are many MOOC designs available on the web such as Chattopadhyay (2015).The following is a summary of the recommendations from various authors as a typical structure that can be adopted for xMOOC.Some of the accepted best practices for MOOC are:

口 It is universally agreed that a typical MOOC is about 8 weeks and 20 hour lectures. Normally most of the university courses are of 3 credits that is about 16 weeks duration and a minimum of 40 hours of lectures. By that token typical MOOC course will be 1.5 credits. This should be the 
( baseline MOOC course.

口 Prepare a very detailed schedule of activities that the student is expected to complete with the MOOC. This should include course learning objectives, course requirements, and a complete and specified path the student should take to complete the course. This should completely indicate the how the lectures will be reinforced by the specific textbook readings, assignments, quizzes and tests. Though it is not necessary for the students to follow this schedule, it is good practice to guide them so that they can achieve a better success when working in even asynchronous mode. In the case of synchronous mode, it will become absolute necessity to provide this information with approximate dates and times so that the students can follow.

u Plan the program in such a way that each of the eight weeks, students should be following one complete topic and the specified learning outcomes. Clearly map the various components of the learning process with the learning outcomes.

口 Make sure that all the material required for learning be made available to the students at all times. They can be the classroom lectures, reading material, any simulations, and other curated material.

口 Make available a standard textbook as part of the reading material. However a commercial textbook often may not be available in some countries, or it may be too expensive for the students to buy. Therefore try to find free resources available in the form of e-books with such initiatives as Open TextbookLibraryhttp://open.umn.edu/opentext books/), CreativeCommonstextbooks(https://creat ivecommons.org/tag/open-textbooks), College opentextbooks(http://www.collegeopentextbooks .org/),Open Education Resources consortium (http://oerconsortium.org/disciplinespecific/), book boon (http://bookboon.com/), etc. Make sure that whatever material being utilized for the course, its intellectual property rights are not violated.

口 Any material that is being developed specifically for the course should follow the general MOOC design principles. The attention span in a web based education will generally be short. Accordingly,lecture videos when developed should not be long but short. The ideal video is considered to be 3 to 7 minutes. In addition, the possibility that many enrolled students may be accessing the material from mobile devices such as smart phones. The information therefore need to be easily accessible and presented in a manner that lends itself to quick assimilation.

口 The typical Course sequence should have the short lecture explaining the concept, followed by some reading assignment to refresh the material, and a small quiz to make sure that the student understands what was given. This should then be reinforced with further explanation by following the same sequence with or without the lecture depending upon the concept in question.

( It is important that the courses developed should follow some standards that will ensure that all aspects of distance education requirements are present in the course. It is good to have some kind of quality assurance for distance education such as Quality atters (https://www.qualitymatters.org/).

口 Provide a discussion space where all the participants can have virtual meetings and discuss various things related to the course. This is the heart and spirit of a MOOC. In order to build a healthy discussion among the people it is necessary to moderate the discussion. For this purpose, it is necessary to have to have experienced community facilitators, clear guidelines, and thoughtful conversation triggers questions, observations, excerpts from the course, personal experience related to the topic - anything that will stimulate discussions. Depending upon the richness of the discussion space, the enrolment will remain strong. This will help to build a healthy community within the course, which may go beyond the course precincts and spill over to coffee hours, lunch conversations, twitter, and other offline and online spaces.

口 Build some good collaborative environment where students will form groups and learn from each other. Group projects are one of the easiest to think of. It is necessary to foster an open culture that promotes collaboration and sharing from one another. This will be helpful for the student when he/she is employed. Ideally, MOOC itself should push the learner to engage in self-driven and authentic learning activities. Course and instructor encourage and enable emergence of learning communities where students connect with each other and with course materials.

u Communication with students should be very clear and consistent and instructors should be very clear about their expectations as well as setting student expectations for the course. Students tend to leave the course if there is confusion.

Q It is possible that many of the students who are enrolled for the first time in a MOOC will struggle $\mathrm{t}$ works. Therefore, a very well written user participation guide along with what to expect as 
$\square$ to figure out how it works. Therefore, a very well written user participation guide along with what to expect as the course evolves, and some fundamentals of social learning will make it easy for them.

口 Prepare a well-planned landing page for your course. This is the place where the student will go to look for details about your course. In a way, it is the place you are advertising your course and make the student enroll in it based on what you present. The MOOC platform that you are using would normally have standard format that you will be following. Normally it will have short video of 1 to 2 minutes where you will explain the course along with other elements. A quick summary of the course at the top should be 30 - 60 words, and this is followed by an expanded version of $100-200$ words in length. Add instructor profiles, recommended background knowledge, course format and a short FAQ section.

\section{Model for Indian Universities}

MOOCs make an excellent case for India. Higher education spending in India is very low with most of it is left to private universities. Poor government regulation in higher education allowed the growth of large number of low quality private educational institutions. Many of those institutions do not even have qualified teachers. The quality of such private institutions is so bad that many of the graduates of such institutions are either unemployed or underemployed. India has one of the largest population of University age students of the world (94 million). With 32 percent of the population in the age group of $0-14$ years, the country is likely to see a further rise in the demand for higher education (Khemka, 2013).

Developing countries formed a major part of the enrollees in Coursera MOOCs besides USA. Table 4 shows the respective percentages of the students from the emerging economies, which was the result of the research conducted by Stanford University using their Coursera MOOC.

Table 4: Coursera Enrollees (Data from Waldrop, 2013)

$\begin{array}{lc}\text { Country } & \text { Enrolment Percentage } \\ \text { US } & 27.7 \% \\ \text { India } & 8.8 \% \\ \text { Brazil } & 5.1 \% \\ \text { Russia } & 2.3 \% \\ \text { Spain } & 4.0 \% \\ \text { Canada } & 3.6 \% \\ \text { Australia } & 2.3 \%\end{array}$

Indian young generation has been visiting MOOC sites regularly. It has been found that more than 80 percent of Indian visitors are under the age of 34 (Khemka, 2013). Indian visitors also spend five times more on these courses than an average visitor toMOOC does. The Indian visitorsare clearly showing the appetite for higher education to either learn somethingentirely new or build upon their knowledge that they already have. Some of theincentives such as curiosity of learning about emerging courses, upgrading their skills atfree of cost, faster promotion in their work places, etc. are driving them.

It is therefore important for Indian universities to come with a slightly modified form of MOOC that can replace part of the regular classes by MOOCs utilizing the resources that are available with the major public universities as a service to the higher education. The following is a suggested for such a purpose.

Suggested MOOC Model for Indian university higher education to offer credit.

1. A team of professionals at the university and other professors from affiliated colleges should identify the courses that could be used as basic courses that will be taught as MOOCs with a blended approach for the purpose of assessment and credit by the University. Ideally, these courses should be from the first year of the four-year B. Tech. degree program to start with and then can be extended for higher years. Then preferably, two persons should be identified as course leaders for each of the course. The choice should be based on the scholarship of the particular course, and experience in teaching the same course over a period in the same university. They will be provided with assistance for developing the course in terms of project manager, content developer, video facility, programming staff, etc. They would also be asked to train other instructors from other colleges who would be taking the responsibility to proctor these courses at their local colleges. To start with, the initial set of courses that will be considered for this model will be all theory with no practical involved. Laboratory based courses need to be planned separately.

2. The University will then approach various affiliated ges. Hopefully, the colleges will understand the advantages of this model to provide quality, and uniform education to all the students and will also train their instructors. It should be made mandatory for all the affiliated colleges that every student should 
colleges with the proposal and the need for them to use it instead of offering at the respective colleges. Hopefully, the colleges will understand the advantages of this model to provide quality, and uniform education to all the students and will also train their instructors. It should be made mandatory for all the affiliated colleges that every student should register for this course and they should not offer any local face-to-face course. The University in consultation with their academic and legal departments should carefully frame the terms and conditions for this to work.

3. Those of the colleges that have agreed to participate would have the benefit getting the credit directly from the University for each of the student so registered.

4. The entire course material in the form of course structure, video lectures, reading material, assignments, quizzes, and final examinations will be streamed by the university through a MOOC platform (such as Edx or Coursera) for all the participants. The course will run in synchronous mode with the complete course structure decided at the beginning of the semester. The registration of the course can be of two types: one for credit from various colleges of the university as well as those who wants to adopt it for their curriculum. The other free students. The free students would not have to complete any assignments and examinations other than quizzes. This will relieve the instructors at the respective colleges of the majority of their teaching time, so that they can concentrate on providing any needed student assistance, evaluate assignments and final examinations (glorified teaching assistants and not instructors). Students will have the opportunity to meet their respective instructor for a face-to-face doubt clearance as and when needed. Some students may have difficulty with access to computer or internet at home, so it is expected that the colleges would make available the computer laboratories with sufficient bandwidth so that such students can complete the course work within the college itself. The same laboratories would be used for proctored examinations to take care of cheating.

5. The grading system will consist of three components. One component is quizzes that will be automatically evaluated. The grade would be made known to the student immediately. The quizzes will be available to all the participants in the course including those that will be taking it simply as a MOOC. The second component consists of assignments that would be graded by the local instructors. These are only available to the students registered for credit. The submission can be either electronic or hardcopy form. Efforts will have to be made to make the evaluation by the instructors as objective as possible so that there will be uniformity among all the colleges. However, the percentage of the grade allowed for assignments is only $25 \%$ so that it should not influence the final grade too much. The third component consists of final examination that needs to be evaluated centrally for the sake of uniformity among all the colleges. Procedures need to be evolved that will help the university to provide uniform correction and grading to award a final grade to the students.

6. Typical MOOC course does not have any prerequisites for the enrollees and that should be fine. However, for providing university credit, a separate model need to be developed to clearly make a distinction between tuition paying student and free student taking the same MOOC.

\section{Conclusions}

Massive Open Online Courses, or MOOCs, have become a global phenomenon. Millions of people have enrolled into free online courses provided by some of the world'smost prestigious universities. The growth in MOOCs was very rapid and there are many models that were developed by different universities and platforms. They certainly have many advantages while many challenges need to be overcome to make them effective. As a free life-long learning process, MOOCs are excellent. It is necessary to examine the pedagogy of the MOOCs that are successfully running, to see that all the best practices are followed for the success of new courses. In the Indian context MOOC should provide a useful tool to help in mass education as well as provide a quality higher education tool. It is therefore important that the administrators and content designers should understand the requirements of MOOCs properly so that they can plan and develop them to be more effective and provide quality courses even in far-flung places of India. A model for giving credit to students who take courses in the form of MOOCs to distinguish between tuition paying student and free student.

\section{References}

[1] Brown, Mark (2013, April 29) 6.003z signals a new open education ecosystem MITx student 
used OCW to create his own massive open online course. (Retrieved on July 7, 2015 from http://newsoffice.mit.edu/2013/6003z-signalsa-new-open-education-ecosystem)

[2] Chang, R. I., Hung, Y. H., \& Lin, C. F. (2015). Survey of learning experiences and influence of learning style preferences on user intentions regarding MOOCs. British Journal of Educational Technology, 46, 3, 528-541.

[3] Chattopadhyay, Sahana(2015, June 1) MOOCs Workplace learning part 2, Designing MOOC, (Retrieved on July 7, 2015 from http://learnnovators.com/moocs-workplacelearning-part-2-designing-mooc/)

[4] Chen, X., Barnett, D. R., \& Stephens, C. (2013). Fad or future: The advantages and challenges of massive open online courses (MOOCs). In Research-to Practice Conference in Adult and Higher Education (pp. 20-21).

[5] Cooper, S., \& Sahami, M. (2013). Reflections on Stanford's MOOCs. Communications of the ACM, 56(2), 28-30.

[6] Cormier, Dave (2 October 2008). "The CCK08 MOOC - Connectivism course, 1/4 way". Dave's EducationalBlog.(http://davecormier.com/edbl og/2008/10/02/the-cck08-mooc-connectivismcourse-14-way/) Retrieved July 7, 2015.

[7] de Waard, I., Koutropoulos, A., Keskin, N., Abajian, S. C., Hogue, R., Rodriguez, O., \& Gallagher, M. S. (2011). Exploring the MOOC format as a pedagogical approach for mLearning. Proceedings from mLearn.

[8] Educause (2013, June). Seven things you should know about MOOCs II. Educause learning initiative. (Retrieved on July 6, 2015 from http://net.educause.edu/ir/library/pdf/ELI7097. pdf).

[9] Hardesty, Larry (2012, July 16) Lessons learned from MITx's prototype course, (Retrieved on $\begin{array}{llllll}\mathrm{J} \text { u } & \mathrm{y} & 7, \quad 2015 & \mathrm{f} \mathrm{r} \mathrm{o} \mathrm{m}\end{array}$ http://newsoffice.mit.edu/2012/mitx-edx-firstcourse-recap-0716)

[10] Higher education MOOCs, Retrieved on July 7, 2015 fromhttp://www.moocs.co/Higher_Educat ion_MOOCs.html

[11] Keller, J. M. (1987). Development and use of the ARCS model of motivational design. Journal of Instructional Development, 10, 3, 2-10.

[12] Keller, J. M. (1999). Using the ARCS motivational process in computer-based instruction and distance education. In M. Theall (ed.), New Directions for Teaching and
Learning: Motivation from Within: Approaches for Encouraging Faculty and Students to Excel. San Francisco: Jossey-Bass, (\#78).

[13] Kennedy, J. (2014). Characteristics of Massive Open Online Courses (MOOCs): A Research Review, 2009-2012. Journal of Interactive Online Learning, 13,1, 1 - 16.

[14] Khemka, Karan (2013, November 4) Moocs might matter even more in emerging markets, (Retrieved on July 7, 2015 from http://www.ft.com/cms/s/0/8bd7ecc4-453e$\begin{array}{lllllllll}1 & 1 & \text { e } & 3 & - & \mathrm{b} & 9 & 8 & \mathrm{~b}\end{array}$ 00144feabdc0.html\#axzz3fAZ7TNxr)

[15] Kop, R. (2011). The challenges to connectivist learning on open online networks: Learning experiences during a massive open online course. The International Review of Research In Open And Distributed Learning, 12(3), 19-38.

[16] Korn, M. (2013, May 14). Coursera makes case for MOOCs. Wall Street Journal (Retrieved on July7,2015fromhttp://online.wsj.com/news/arti cles/SB10001424127887324715704578483570 761525766).

[17] Leber, J. (2013, March 15). In the developing world, MOOCs start to get real. MIT Technology Review. (Retrieved on July 7, 2015 from http://www.technologyreview.com/news/51225 6/in-thedeveloping-world-moocs-start-to-getreal/)

[18] Mackness, J., Mak, S. \& Williams, R. (2010). The ideals and reality of participating in a MOOC.In: Proceedings of the 7th International Conference on Networked Learning 2010. University of Lancaster, Lancaster, pp. 266-275.

[19] Margaryan, A., Bianco, M., \& Littlejohn, A. (2015). Instructional quality of Massive Open Online Courses (MOOCs). Computers \& Education, 80, 77-83.

[20] McGreal, R., Conrad, D., Murphy, A., Witthaus, G., \& Mackintosh, W. (2014). Formalising informal learning: Assessment and accreditation challenges within disaggregated systems. Open Praxis, 6(2), 125-133.

[21] Naidu, S. and Barberà, E. (2014) The Weakest Link - Assessment and Accreditation in MOOCs, Digital Education Review, 25, 1-6.

[22] Rodriguez, C. O. (2012). MOOCs and the AIStanford Like Courses: Two Successful and Distinct Course Formats for Massive Open Online Courses. European Journal of Open, Distance and E-Learning. Retrieved on July 7, 2015 fromhttp://www.eurodl.org/materials/cont 
rib/2012/Rodriguez.pdf

[23] Selwyn, N., Bulfin, S., \& Pangrazio, L. (2015). Massive open online change? Exploring the discursive construction of the 'MOOC' in newspapers. Higher Education Quarterly, 69(2), 175-192.

[24] Spyropoulou, N., Pierrakeas, C., \& Kameas, A. (2014). Creating MOOC Guidelines Based On Best Practices. EDULEARN14 Proceedings, 6981-6990.

[25] Taneja, S., \& Goel, A. (2014). MOOC Providers and their Strategies. International Journal of Computer Science and Mobile Computing, 3(5), 222-228.

[26] Toven-Lindsey, B., Rhoads, R. A., \& Lozano, J. B. (2015). Virtually unlimited classrooms: Pedagogical practices in massive open online courses. The Internet and Higher Education, 24, $1-12$.

[27] UNESCO (2013) Introduction to MOOCs: Avalanche, Illusion or Augmentation?, UNESCO Institute Policy Brief, (Retrieved on

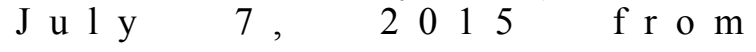

http://iite.unesco.org/pics/publications/en/files/ 3214722.pdf)

[28] Vardi,MosheY.(2012)Will MOOCs destroy academia? Communications of the ACM, 55, 11, 5.

[29] Waldrop, M. M. (2013, March 13). Massive open online courses, aka MOOCs, transform higher education and science, Scientific American, (Retrieved on July 7, 2015 from http://www.scientificamerican.com/article/mas sive-open-online-courses-transform-highereducation-and-science/)

[30] Walker, L., \& Loch, B. (2014). Academics' perceptions on the quality of MOOCs: An empirical study. INNOQUAL-International Journal for Innovation and Quality in Learning, 2,3,53-63.

[31] Wikipedia Massive Open Online Course, (Retrieved on July 7, 2015 from https://en.wikipedia.org/wiki/Massive_open_o nline_course) 